\title{
Traveling Image of the Holy Child of Atocha (Santo Niño de Atocha), Plateros, Mexico
}

Jennifer Scheper Hughes and Daisy Vargas

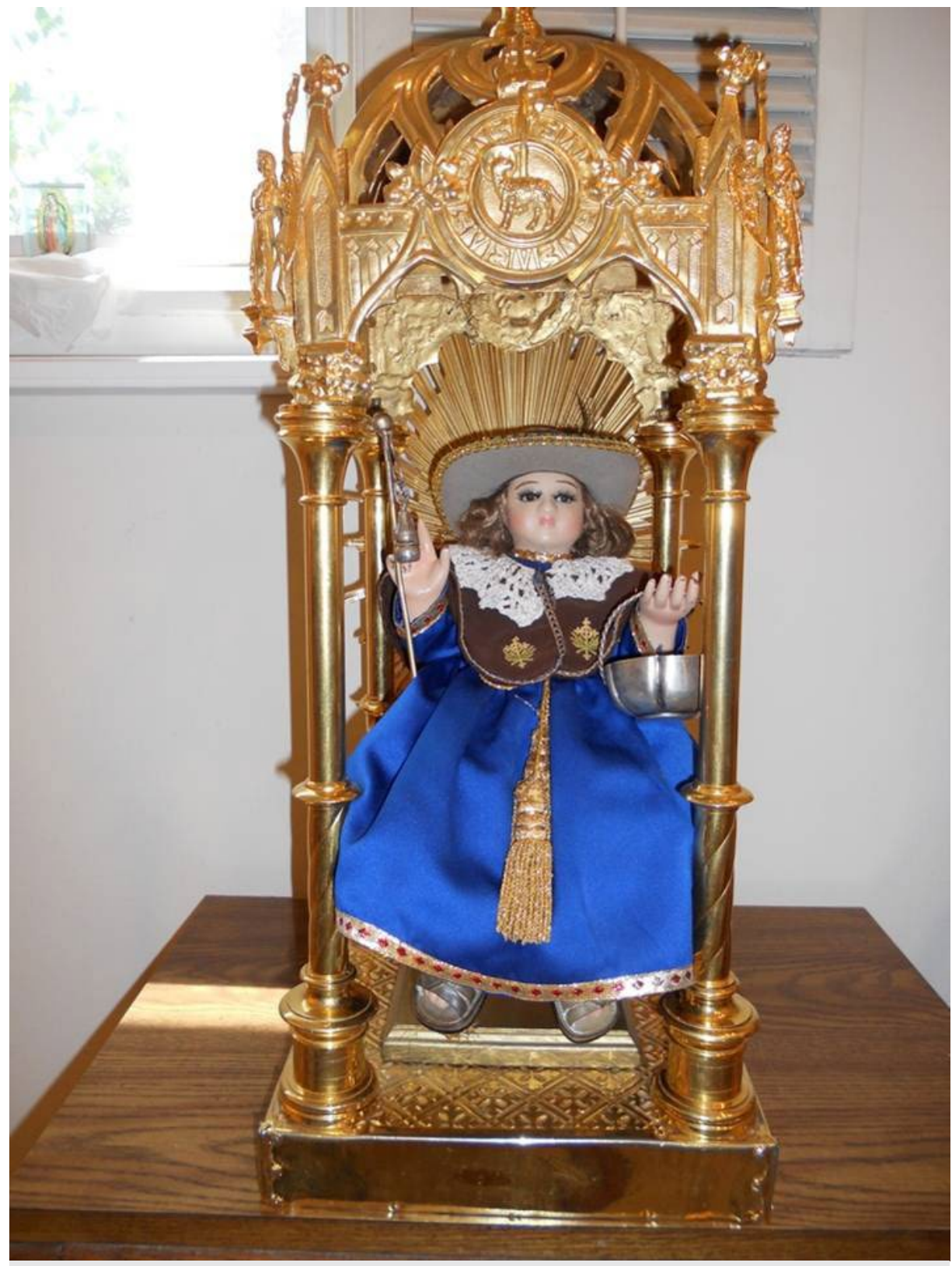

The traveling image of the Niño de Atocha, installed at Our Lady of Guadalupe Church in Santa Paula, California.

Each year, certain special religious images are ceremonially brought from Mexico and Central America to visit Catholic devotional communities in Southern California. These devotional statues of Catholic saints are "imágenes peregrinas," pilgrim or traveling images. They are official replicas of esteemed images from regionally and 
nationally significant shrines and sanctuaries. ${ }^{1}$ More than inert objects, they are material manifestations of the sacred that are understood to bestow blessings on an otherwise barren American spiritual landscape. These sacred objects-entities possess a power and potency that their devotees often feel they lack in an increasingly tenuous political and economic climate. Since 2006, a traveling image of the Santo Niño de Atocha from Plateros, Mexico (a small silver mining town in the Mexican state of Zacatecas) has made an annual pilgrimage to the predominantly Latino southern California city of Santa Paula. ${ }^{2}$ Traveling images like the Santo Niño create and sustain linkages between sending communities and migrants living in the United States. ${ }^{3}$

The original Mexican Niño de Atocha was installed in a local church not long after a silver strike in Plateros in 1554. Drawing on Iberian Catholic traditions, the original image was popular among Spanish colonials. Royally adorned, his significance was tied to the Spanish monarchy and therefore to the imperial colonial project. As the devotion spread among mestizo and indigenous miners, subsequent modifications in Mexico altered his identity from prince to pilgrim: his crown traded for a straw hat, his globe for a basket, and his scepter for a humble pilgrim's staff. ${ }^{4}$

Celebration of the Niño has flourished in Santa Paula with the support of an Anglo (non-

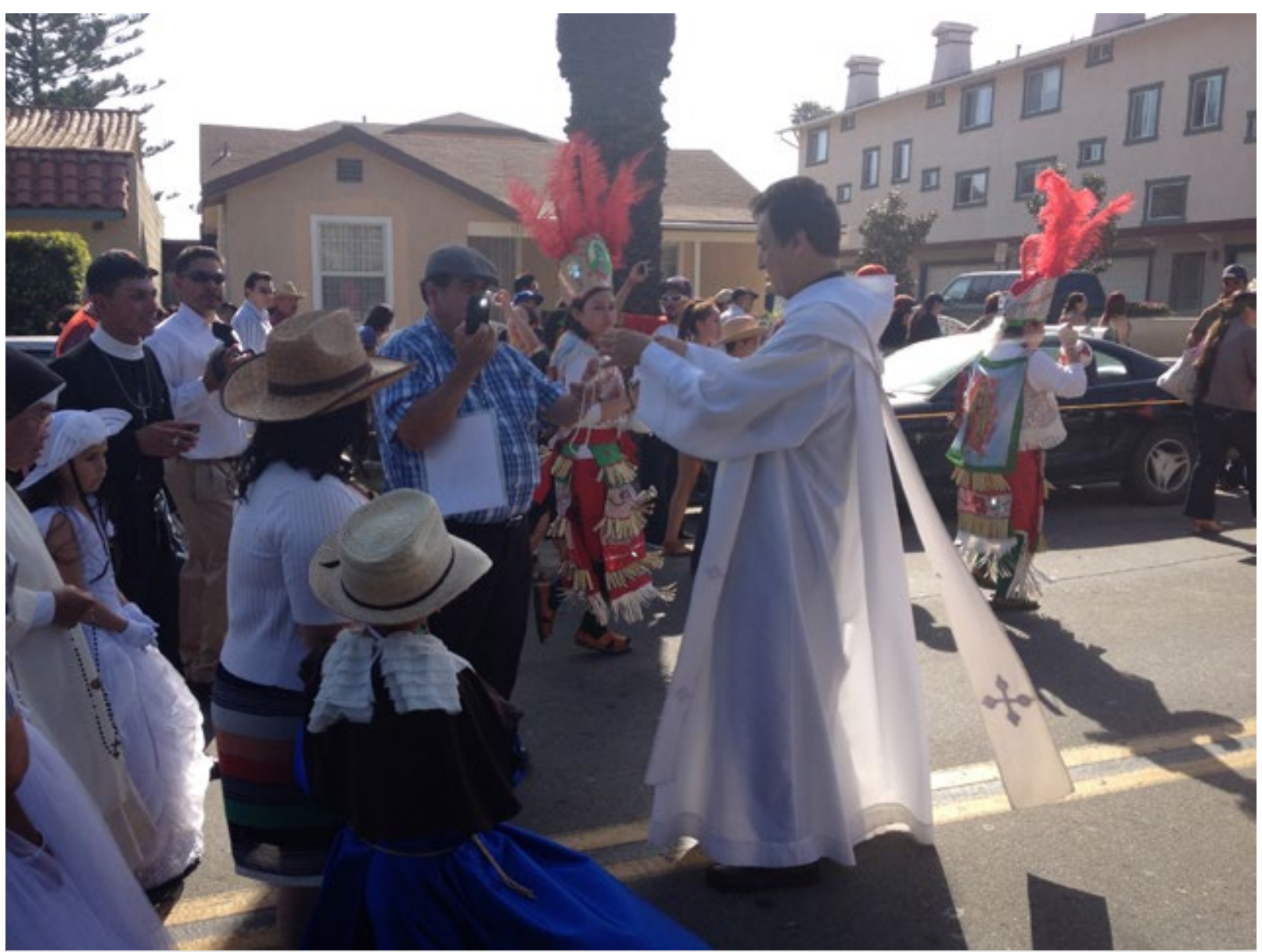

Padre Carlos blessing rosary beads at the procession of the Santo Niño de Atocha in Santa Paula, California. 
Mexican) Catholic priest, Father Charles, or "Padre Carlos" as he is affectionately known by parishioners. It was Padre Carlos who, seven years ago, first organized to have the replica image from Plateros visit his predominantly Latino California parish, Our Lady of Guadalupe Catholic Church. The pastor is warmly regarded by his parishioners: "He loves our [Mexican] traditions, and he likes keeping his community happy by bringing santos [saints' images] from Mexico to our church," one Santa Paula woman parishioner observes. ${ }^{5}$ Many members of the community understand Santa Paula to be the Santo Niño de Atocha's "second shrine."

Each year, the Santo Niño image travels by plane from Zacatecas to California in the protective arms of his priest-escort, usually the rector of the Plateros shrine. In 2013, the annual celebration was threatened when the Mexican priest misplaced his passport. Rather than cancel the visit, Padre Carlos himself boarded a hastily-booked flight and

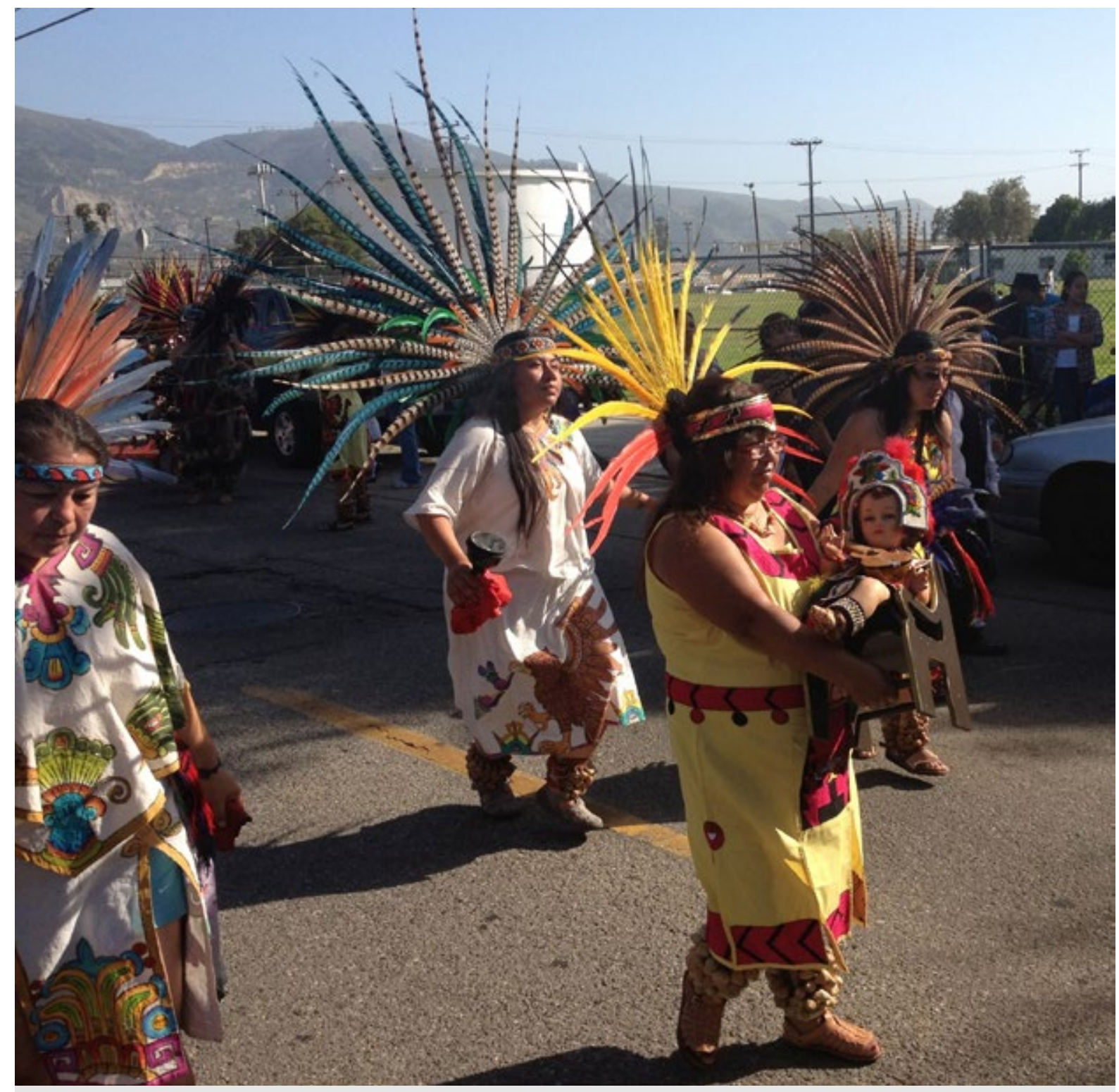

Padre Carlos blessing rosary beads at the procession of the Santo Niño de Atocha in Santa Paula, California. 


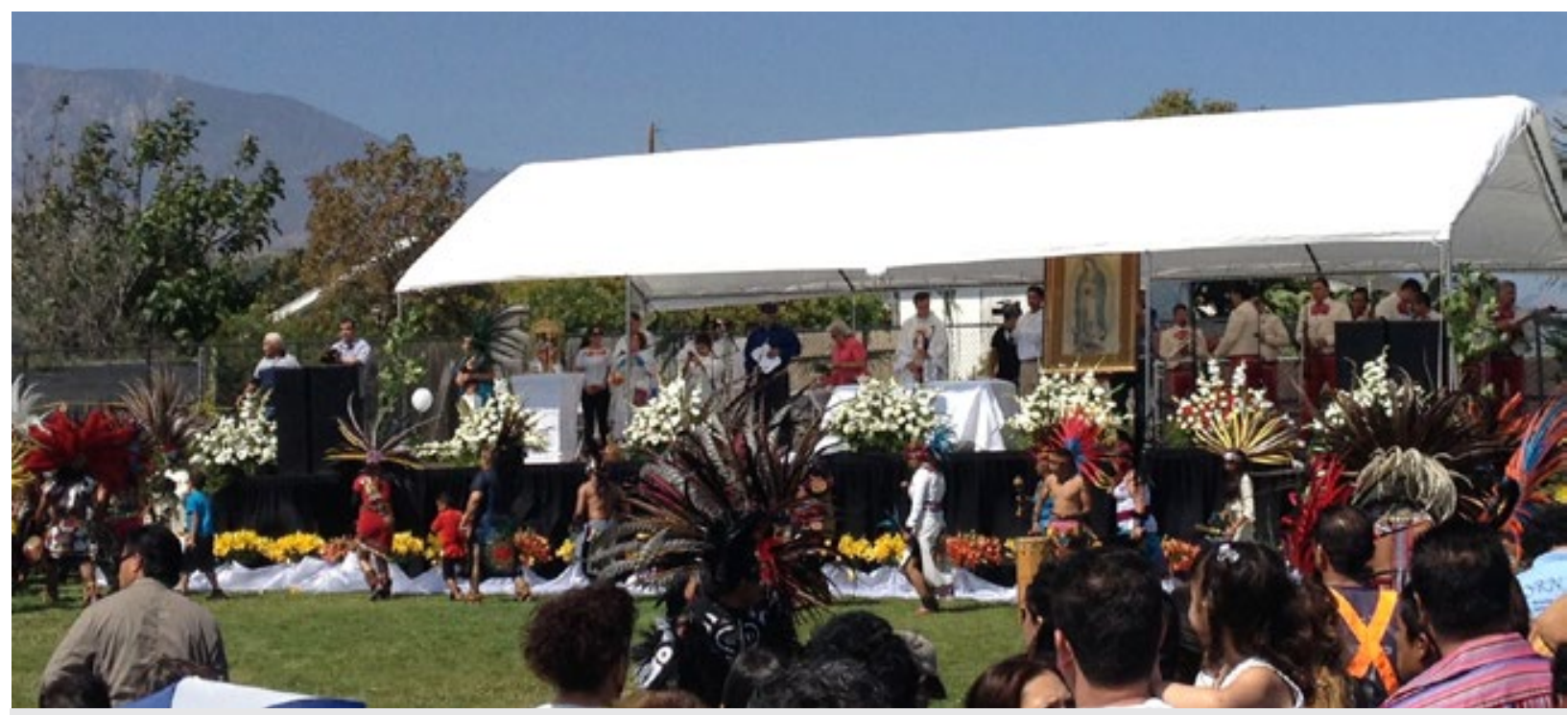

Outdoor Mass following the street procession. The Niño sits under a large tent as dozens of concheros, Aztec-style folk dancers, pay him tribute. A mariachi band prepares their instruments to accompany the mass.

personally escorted the image to Santa Paula. Indeed, the problem of migration and immigration figures predominantly in discourse about the Niño and his celebration. In the last decade, return migration by pilgrims hoping to visit Mexican shrines has become increasingly challenging. Stronger policing of the border, including the "double-barreled" border fence has made it more difficult for those without legal status to travel home to pay homage to patron saints. Drug-related violence has also hindered pilgrimage to the Plateros shrine. ${ }^{6}$ Yet, the Niño is able to subvert geopolitical boundaries where his devotees cannot. While the original image must remain in Zacatecas, the traveling Niño is a pilgrim and migrant. As one Santa Paula devotee explains, he "has the green card."

A raucous street procession welcomes the Niño to Santa Paula: concheros, Aztec-style folk dancers, from as far afield as Las Vegas, amplified music, and crowds upwards of 5,000 disrupt the normally tranquil streets of Santa Paula. The Niño is processed on an elaborately adorned litter. Devotees jostle for their turn to help carry him. Father Carlos marches proudly in the procession, enthusiastically blessing rosaries, images, and other religious objects brought to him by parishioners. The image itself dispenses blessings as devotees approach the Christ child and press holy cards, rosary beads, and small statues to him. ${ }^{8}$ The Santo Niño spends at least two weeks in the local parish church where he receives devotees from throughout California who pray before the image and leave letters of petition, flowers, toys, and other modest offerings. After a farewell procession, the Niño returns.

Through public celebrations like those in honor of the Niño de Atocha, Latino devotees of traveling images create alternative models of participation in the American religious landscape. Traveling devotional images like the Santo Niño delineate new geographies of transborder sacred power by forging ties between Mexican sacred sites and migrants living and laboring in the United States. What emerges is a potent, spiritual bi-localism 
in which particular sites on both sides of the border are marked as sacred. These sites are ritually linked through annual pilgrimage that, in the context of decreasing mobility of migrants themselves, is undertaken by the traveling image who makes the journey in their stead. Traveling devotional images and public religious celebrations associated with their cyclical migrations challenge normative Protestant-based American ideals of immigrant acculturation and assimilation into "the imagined American community." 9

(C) Jennifer Scheper Hughes and Daisy Vargas

\section{Citation Guide}

1. Jennifer Scheper Hughes and Daisy Vargas, "Traveling Image of the Holy Child of Atocha (Santo Niño de Atocha), Plateros, Mexico," Object Narrative, in Conversations: An Online Journal of the Center for the Study of Material and Visual Cultures of Religion (2014), doi:10.22332/con.obj.2014.35

Scheper Hughes, Jennifer and Daisy Vargas. "Traveling Image of the Holy Child of Atocha (Santo Niño de Atocha), Plateros, Mexico." Object Narrative. In Conversations: An Online Journal of the Center for the Study of Material and Visual Cultures of Religion (2014). doi:10.22332/con.obj.2014.35

\section{Notes}

1. A relatively recent issue of the performance studies journal, E-mésferica (5:1 2008) was devoted to the topic of "traveling virgins" (virgenes viajeras).

2. The population of Santa Paula is just shy of eighty percent Latino (all but 2.8 percent of whom are Mexican-American) and almost homogenously workingclass http://factfinder2.census.gov/faces/tableservices/jsf/pages/productview. xhtml?pid=ACS $11 \quad 5 \mathrm{YR}$ DP05

3. In 1999, a replica of the Virgin of Guadalupe traveled to Los Angeles, culminating in a celebratory liturgy on the Virgin's feast day on December 11 at the Los Angeles Coliseum attended by some 50,000 faithful.

4. Juan Javier Pescador. Crossing Borders with the Santo Niño De Atocha. Albuquerque: University of New Mexico Press, 2009), 85.

5. Research in Santa Paula, including participant observation and interviews, was conducted in the spring of 2012 and 2013 through the Institute for the Study of Immigrant Religions at the University of California, Riverside. Research assistant, Aracely Vasquez offered particular assistance.

6. In 2009, a firefight between drug cartels left a half dozen people dead in nearby Fresnillo and a shooting on July 1, 2011 was in close proximity to the shrine. Martinez, Osvaldo. "Federal Forces and Zetas wage daylong fight in Fresnillo, Zacatecas." 
BorderLand Beat. July 2001. http://www.borderlandbeat.com/2011/07/federal-forcesand-zetas-wage-daylong.html

7. http://www.santapaulatimes.com/news/archivestory.php/aid/27429/El_Santo_Ni_ F1o_de_Atocha:_Arrival_of_icon_in_Santa_Paula_a_joyous_occasion.html

8. Devotional practice in the 2012 procession: http://www.youtube.com/ watch?v=8Le1xcJpPBY Accessed on June 23, 2013.

9. Luis D. Leon. "Metaphor and Place: The U.S.-Mexico Border as Center and Periphery in the Interpretation of Religion." Journal of the American Academy of Religion 67, no. 3 (September 1999), 567.

\section{Yale}

Copyright 2016 Yale University All rights reserved. 